\title{
Integrating Innovative Entrepreneurship with Engineering Education
}

\section{Dr. Pradeep Kashinath Waychal, NMIMS University}

Dr Pradeep Waychal is a founder trustee and the chair of Guruji Education Foundation that provides holistic support to the education of underprivileged students and operates on funding from friends. The foundation has recently extended its work in diverse areas such research in engineering education, youth employability and teaching computer science to adolescents. Earlier, Dr Waychal has worked at Patni Computer Systems for 20 years in various positions including the head of innovations, NMIMS as the director Shirpur campus and at College of Engineering Pune (COEP) as the founder head of the innovation Center.

Dr Waychal earned his Ph D in the area of developing Innovation Competencies in Information System Organizations from IIT Bombay and M Tech in Control Engineering from IIT Delhi. He has presented keynote / invited talks in many high prole international conferences and has published papers in peerreviewed journals. He / his teams have won awards in Engineering Education, Innovation, Six Sigma, and Knowledge Management at international events. Recently, his paper won the Best Teaching Strategies Paper award at the most respected international conference in the area of engineering education - Annual conference of American Society of Engineering Education (ASEE). His current research interests are engineering education, software engineering, and developing innovative entrepreneurs and intrapreneurs.

\section{Prof. Ashok Ranade, EE Collaborative}

Ashok has worked as Information Technology specialist in India, USA and Canada for more than 40 years in various capacities. He founded several IT services businesses. He is teaching subjects related to Entreprise Systems and Entrepreneurship Developent at multiple colleges in India and Canada. 


\section{Identifying Entrepreneurial Competencies: An Indian Study}

\section{Introduction}

Entrepreneurship has become more critical than ever for all the economies. It requires competent individuals, and capable institutions to nurture those individuals. We need to identify, assess and develop entrepreneurial competencies of individuals and identify requirements, assess and develop capabilities of institutions to meet those requirements in order to breed successful entrepreneurs (Figure 1). This paper concentrates on identifying competencies of individuals.

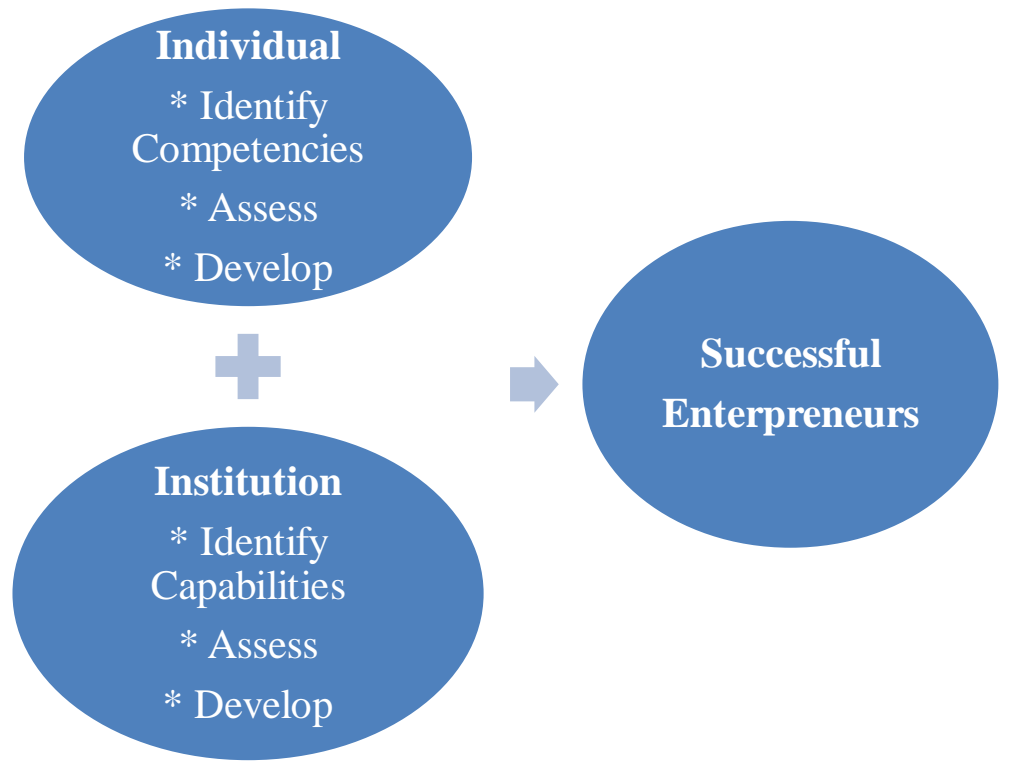

Figure 1: Developing Successful Enterpreneurs

Association of Talent Development (ATD - earlier ASTD) has defined competencies as knowledge, skills, abilities, and behaviours ${ }^{1}$. Different researchers have used terms such as entrepreneurial skills, attributes, characteristics, mindset, behaviour, etc. We are using the term competency to refer all those terms unless we are citing specific research. Lichtenstein \& Lyons ${ }^{2}$ emphasized that developing entrepreneurs is developing skills. The development is being promoted, for quite some time, in education institutions in European, Asian and African countries ${ }^{3}$. The US education system has been witnessing a growing trend in teaching and encouraging entrepreneurship at college level ${ }^{4}$. This trend has not slowed and has resulted in over 2000 colleges offering courses in entrepreneurship ${ }^{5}$. A Guide for Educators by the European Commission-DG Enterprise \& Industry, Brussels points out that entrepreneurship education is more than preparation on how to run a business. It adds that it is about how to develop the entrepreneurial attitudes, skills and knowledge which, should enable a student to 'turn ideas into action' ${ }^{6}$. Kauffman Campus initiative ${ }^{7}$ found that isolated entrepreneurial education initiatives - as against the ones integrated with the whole program - tend to fail ${ }^{5,8}$. 
Charney and Libecap ${ }^{9}$ assessed impact of entrepreneurship education and found that the education produces self-sufficient and innovative enterprising individuals.

Simpeh ${ }^{10}$ examines various entrepreneurship theories including psychological entrepreneurship theories. The psychological theories highlight personal characteristics that define entrepreneurship. Simpeh has included "traits theory" and "need for achievement theory" in the paper ${ }^{10}$. The "trait theory" hypothesizes that an individual has inborn qualities or potentials that naturally make him an entrepreneur. The issue with the trait model is that, there is no consistent evidence of unique entrepreneurial characteristics ${ }^{11}$. Simpeh also quotes McClelland's "need for achievement theory" that argues that human beings have a need to succeed, accomplish, excel or achieve. While entrepreneurs have such need to succeed, there does not seem to be any evidence for the relationship between achievement motivation and entrepreneurship ${ }^{10}$.

Kirby ${ }^{12}$ states that successful entrepreneurs have characteristics (competencies) and they must be developed to meet entrepreneurial challenges of the twenty-first century and asserts changing emphasis from educating "about" entrepreneurship to educating "for" it. Gurol and Atsan ${ }^{3}$ argue that that there is a clear need to seek to identify the personality traits and skills (competencies) that are required of successful entrepreneurs to develop entrepreneurial education and training curriculum. Rasmussen, et al. argue that a competency focus necessitates consideration of the human aspects of the entrepreneurial process ${ }^{13}$.

We posit that engineering profession requires more entrepreneurial skills than others do. In fact Fred ${ }^{14}$ quote a CEO saying that "If an engineer is not an entrepreneur, he is just a tool". Therefore, it is imperative that engineering education includes entrepreneurial elements. Kriewall $\&$ Mekemson ${ }^{15}$ assert that engineers have unique perspective on leveraging technology and note that entrepreneurial education in engineering schools requires more emphasis. Duval, et al. argue that changing global economic and workforce trends evoke keen interest among policy makers and educational stakeholders to build more engineers with entrepreneurship skills and an entrepreneurial mindset in order to better prepare them for a fast-changing professional environment ${ }^{16}$.

Kern Entrepreneurial Education Network (KEEN) has evolved a framework to develop entrepreneurial mindset (EM). Representatives from the $15 \mathrm{KEEN}$ schools collaborated during fall and winter of 2010/11 to develop a set of student learning outcomes that capture what the cohort considered essential elements of the entrepreneurial mindset ${ }^{5}$. Kleine and Yoder ${ }^{17}$ have presented an approach on operationalizing and assessing the KEEN entrepreneurial mindset. Israel seems to have come up with an excellent entrepreneurial development system resulting in the highest number of per capita start-ups. The system is described by Senor and Singer ${ }^{18}$ that can give rise to its own framework. Gurol and Atsan ${ }^{3}$ have defined entrepreneurial profile based on six traits (competencies) derived from literature survey and evaluated entrepreneurial orientation of senior engineering students from Turkey. Stanford University's Epicenter has 
been offering entrepreneurship and innovation programs for engineering faculty and students, and has been collaboratively building a national entrepreneurship agenda in engineering education ${ }^{19}$. We also studied more models such as Entrepreneur Skill Theory (EST) proposed by Lyons ${ }^{20,21}$, General Measure of Enterprising Tendencies (GET2) proposed by Caird ${ }^{22}$ and Entrepreneurial Mindset Profile (EMP) proposed by Davis, et al. ${ }^{23}$. All these three authors have developed instruments to assess entrepreneurial competencies.

Educators all over the world are trying to work towards developing entrepreneurial competencies. They are following various methods such as developing freshman design course ${ }^{24}$, a multi-course problem-based learning ${ }^{25}$, a two semester a course on technology-based entrepreneurship ${ }^{26}$ and even having an entrepreneurship minor ${ }^{27}{ }^{28}$. Yoder, et al. present efforts on faculty development to foster entrepreneurial mindset of students ${ }^{29}$. Schakett ${ }^{5}$ has reported introduction and operationalization of development of the entrepreneurial mindset (EM) in a multidisciplinary environment. We also came across a report that examines pedagogical justification of including entrepreneurship in engineering education ${ }^{30}$. The European Commission ${ }^{6}$ report states that entrepreneurship competency development does not necessarily involve a specific school subject, instead it requires a way of teaching (that can be adopted by all the subjects) in which experiential learning and project work have a main role . Further, the report adds that the development efforts have to inspire students to develop an enterprising attitude and require school environment where creativity and risk-taking are encouraged, and mistakes are valued as a learning opportunity ${ }^{6}$.

\section{Research Design}

Most of the studies on entrepreneurship relate to developed and not developing or emerging economies ${ }^{31,32}$. It has become important to study the emerging economies as they are growing rapidly. By 2025, BRIC (Brazil, Russia, India, and China) economies are predicted to be of half the size of the G6 (United States, Japan, Germany, U.K., France, and Italy) economies. Despite that, there are extremely limited research efforts, particularly on Brazil, Russia, and India ${ }^{33}$. Peng has shown that findings in a developed economy in domains such as strategy are not equally applicable to emerging economies ${ }^{34}$. We posit the same to be true for research in entrepreneurship area. Thus, there is a critical requirement to assess application of the proposed and established entrepreneurial theories to the developing economies. The reasons such as emergence of the global economy, higher unemployment rates in developing economies ${ }^{35}$ and entrepreneurs' potential to create employment contribute to the requirement ${ }^{36}$. Acs and Virgill ${ }^{37}$ have studied increased focus on entrepreneurship in developing countries due to poor experience with import substitution and export promotion initiatives undertaken earlier. They point out that entrepreneurship can be a good growth engine for developing countries and assert that the entrepreneurship will require a different approach. Amongst many things, they emphasize on human capital development in the developing countries. John-Paul has studied entrepreneurship in developing economies and presented factors that act as barriers to entrepreneurship ${ }^{38}$. Ejah et al. have studied entrepreneurship in India and indicate that factors such as quality of physical 
infrastructure and workforce education (competencies) are the strongest predictors of entrepreneurial successes, with labour laws and household banking access also playing important roles ${ }^{31}$. In this study, we are focusing on entrepreneurial competencies in India. We present our research design in figure 2.

\section{Survey of successful}

Indian entrepreneurs to

decide competencies of

successful entrepreneurs

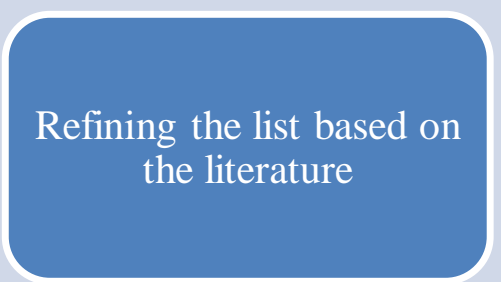

Deriving the top

competencies based on

views of expert

entrepreneurs that have

exposure to Indian and

International environments

Figure 2: Research Design

Survey of successful Indian entrepreneurs

Since, the probability sampling techniques used for quantitative studies are rarely appropriate for qualitative studies ${ }^{39}$, we used judgement i.e. purposeful sampling with an element of convenience sampling. We actively selected the most productive sample to understand competencies required for an entrepreneur to succeed from successful Indian entrepreneurs. We discussed possible respondents i.e. successful entrepreneur's with the core team consisting of three professionals working on the entrepreneurship education for several years. We came up with a list of 98 successful entrepreneurs and surveyed those using Google forms. We had to follow up with some of them. Almost all the respondents were in core engineering and allied areas (such as placement, coaching and accounting services). Two entrepreneurs were from the social and nursing areas. We provide demographics of the respondents in figure 3 that indicates we had a representative sample. 

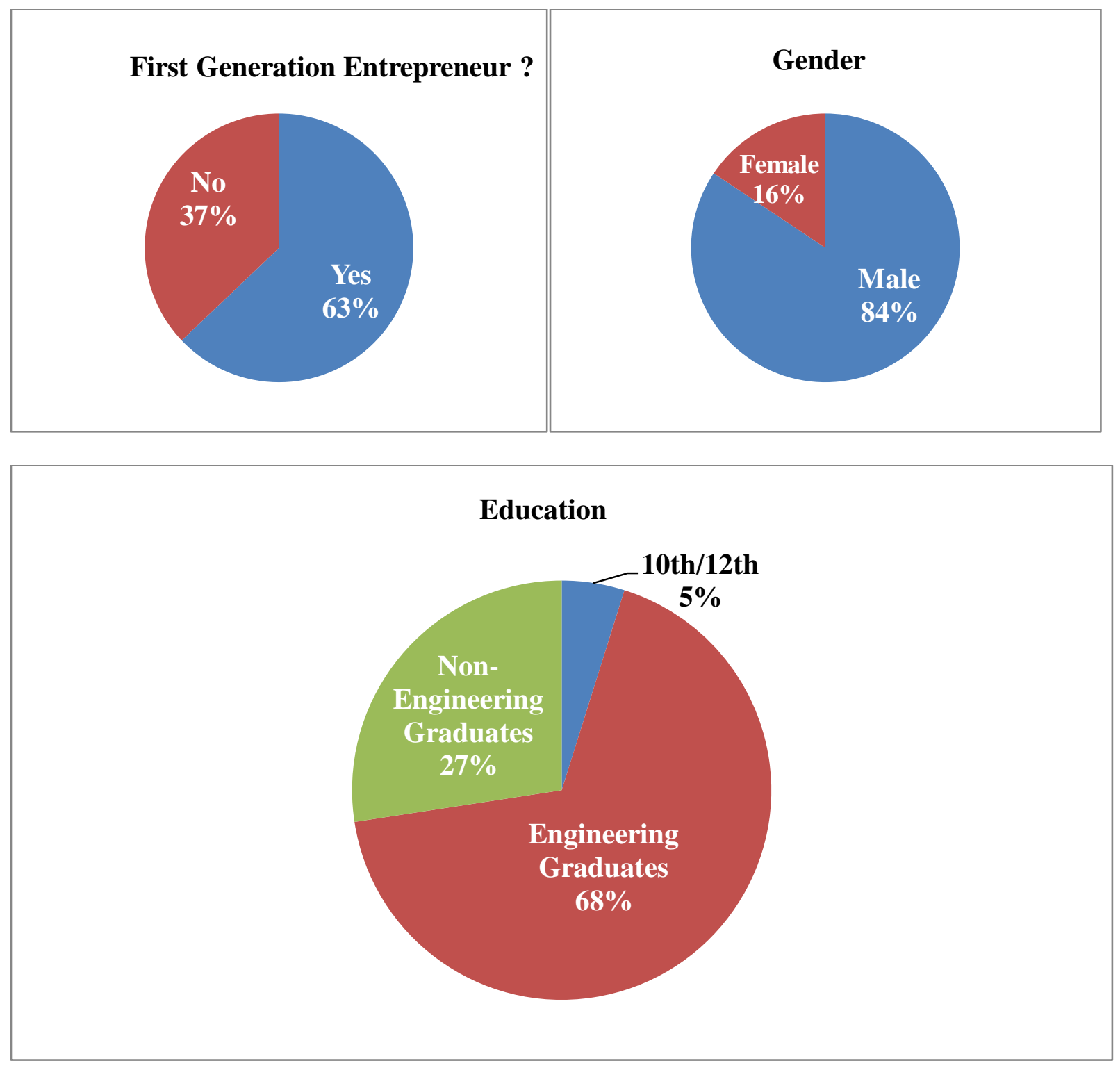

Figure 3: Demographics of the entrepreneurs who participated in the survey

We asked the successful entrepreneurs to list the three most important competencies, in the order of importance, required of a successful entrepreneur. We also asked them to describe briefly each competency. In that sense, this was an open-ended survey. Jackson and Trochim point out that open-ended questions are used in organizational research to explore, explain, and/or reconfirm existing ideas and provide rich description of respondent reality at a relatively low cost to the researcher ${ }^{40}$. Pothas et al. argue that open-ended questions ensure that the monitoring of customer satisfaction keeps up with the changing aspects deemed relevant by the customers ${ }^{41}$. Sproull believes that open-ended questions allow to explore different dimensions of respondents' experiences ${ }^{42}$. Such surveys also pose challenges in analyzing responses ${ }^{40}$. Moreover, respondents may not be able to take holistic view and miss some critical aspects. Overall, 
Jackson and Trochim mention that open-ended survey responses are extremely useful in helping to explain or gain insight into organizational issues 40 .

We have a group of professionals who is working on developing entrepreneurs. We relied on their network and reached out to 98 entrepreneurs. We received responses from 67 successful entrepreneurs. We defined success as the enterprise being active and in business at least for a year. We also had asked the successful entrepreneurs if they would like to join the expert panel to help upcoming entrepreneurs. Forty of them showed readiness. Four of the twenty who did not, had recommended their friends to take survey and seven others had given some suggestions for the study. Three of the seven who did not respond to the question also had some suggestions. This indicates that almost all the respondents were serious about the survey, connoting reliability and validity of the survey data.

We used the constant comparative method ${ }^{43}$ to analyse the qualitative inputs to derive the most important competencies of successful entrepreneurs. We have plotted them in figure 4. 'Clear vision' emerged to be the most important competency. Leadership, decision-making skills, passion, dedication and hard work appeared to be second most important set of competencies.

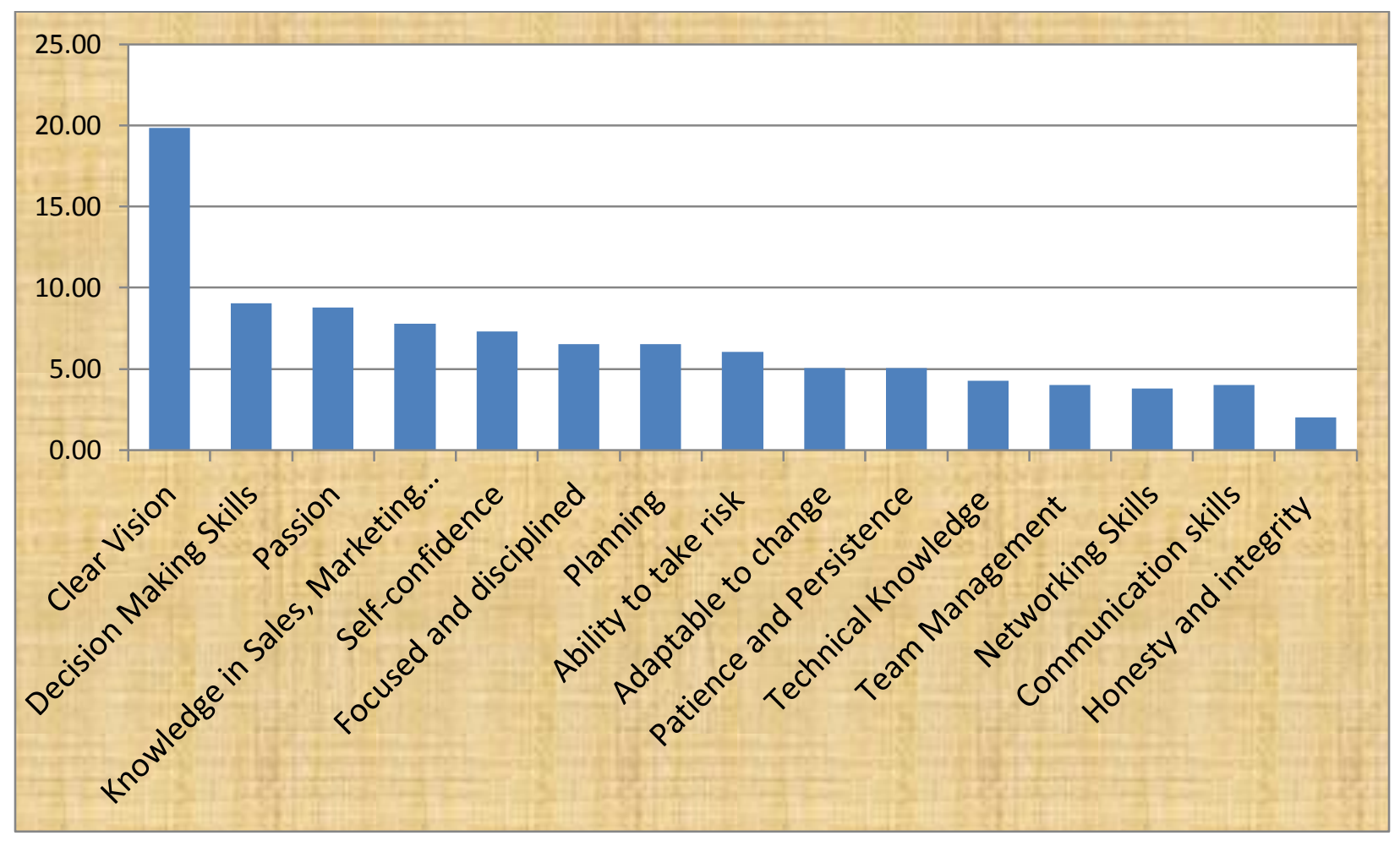

Figure 4: The most important competencies of successful entrepreneurs, as suggested by the successful entrepreneurs 
Refining the list

Since we had asked open-ended questions, the survey respondents may have missed some competencies. Therefore, we studied the prevalent models such as Entrepreneur Skill Theory (EST) by Lyons ${ }^{20,21}$, General Measure of Enterprising Tendencies by Caird ${ }^{22}$, Entrepreneurial Mindset Profile by Davis, et al. ${ }^{23}$, KEEN foundation model ${ }^{5}$ and Israel model as articulated in 'Start-up Nation' ${ }^{18}$ to refine the set of competencies and arrived at the list as given in table 1. The list was synthesized by the authors and reviewed by a third party entrepreneurial educator.

\begin{tabular}{|c|c|}
\hline Clear Vision & Creativity and Innovation \\
\hline Decision Making & Action Orientation - Agility \\
\hline Passion & Nonconformity \\
\hline \multicolumn{2}{|c|}{ Knowledge in Sales-Marketing and } \\
\hline Finance & Curiosity - Questioning \\
\hline Self-Confidence & Opportunity Spotting \\
\hline Focused and Disciplined & $\begin{array}{l}\text { Integrate information from many sources to gain } \\
\text { insight }\end{array}$ \\
\hline Planning & Persist through and learn from failure \\
\hline Execution & Convey engineering solutions in economic terms \\
\hline Risk Taking & Fulfill commitments in a timely manner \\
\hline Adaptability to Change & Discern and pursue ethical practices \\
\hline Patience and Persistence & Contribute to society as an active citizen \\
\hline Technical Knowledge & Life-long Learning \\
\hline Networking & Ambitious but collective \\
\hline Team Management & Aggressive but nurturing \\
\hline Communication Skills & Critical Thinking \\
\hline Honesty and Integrity & Emotional Maturity \\
\hline Achievement Orientation & Interdisciplinary approach \\
\hline
\end{tabular}

Table 1: The enriched list based on the survey and the leading models 
Deriving the top competencies based on views of expert entrepreneurs

We then sought views of six entrepreneurial experts, who have exposure to Indian and international entrepreneurial ventures, to discern between the table 1 competencies to arrive at a shorter list. The experts were either serial entrepreneurs and/or responsible for evaluating and nurturing start-ups across the world with primary focus on India. We asked them to rate each competency as the first, second and third level requirements and allocated weights of 3,2,1, respectively. Based on their inputs, we arrived at the top nine competencies as listed in table 2. Many researchers and regulatory bodies have prepared lists of competencies required of today's engineers. We compared our list with the list of global engineers' attributes published by Huntley ${ }^{44}$. We chose this as it appears to be the latest list. Huntley's list includes two technical knowledge attributes i.e. demonstrates an understanding of engineering, science, and mathematics fundamentals and demonstrates an understanding of information technology, digital competency, and information literacy unlike our list. Self-confidence and team-management are common in both the lists. Huntley has included many sub attributes in team management.

Achievement orientation from our list can be matched with shows initiative from Huntley's list. Critical and creative thinking are not but vision, passion, execution, risk taking, decision-making, and adaptability to change are part of our list.

\begin{tabular}{ccc}
\hline Competency & Average & Standard Deviation \\
\hline Self-Confidence & 2.83 & 0.41 \\
Clear Vision & 2.67 & 0.52 \\
Passion & 2.67 & 0.82 \\
Execution & 2.67 & 0.52 \\
\hline Risk Taking & 2.67 & 0.52 \\
\hline Decision Making & 2.50 & 0.55 \\
\hline Adaptability to Change & 2.50 & 0.84 \\
\hline Team Management & 2.50 & 0.55 \\
\hline Achievement Orientation & 2.50 & 0.84 \\
\hline
\end{tabular}

Table 2: List of the top nine competencies based on inputs of experts in entrepreneurship 


\section{Future Directions}

We propose developing a framework for assessing, and building identified entrepreneurial competencies using various modules / courses, pedagogical techniques and initiatives. We also intend to analyze the reasons for the competencies being important particularly in the Indian and international context. We are studying various entrepreneurial assessment instruments and coming up with guidelines for their usages. Nurturing entrepreneurship requires capable individuals and capable institutions. We are aware that we cannot add more credits or workload on the pretext of developing entrepreneurial competencies. Therefore, our framework would attempt to integrate the entrepreneurial requirements in the current curriculum and extracurricular and co-curricular activities as much as possible. We expect institutions to customize the framework - based on their creative ideas and their institutional requirements - to formulate a blueprint for developing innovative entrepreneurs from their institutes. We are researching attributes of such capable institutes and are developing institutional capability assessment model. We also are working on developing case studies of institutes that are successful in developing entrepreneurs.

\section{Concluding Remarks}

The need for entrepreneurship was never more pronounced, than it is today. For a developing country such as India, the need is more severe as that is the only way to leverage demographic dividend and not allow it to turn into a demographic disaster. That requires building Indian models for developing individuals as potential entrepreneurs and preparing institutions for nurturing those individuals by giving proper inputs and support. Towards that, we have gathered inputs from Indian entrepreneurs as well as utilized global entrepreneurial research to arrive at the most important Indian entrepreneurial competencies. That has been the major contribution of the study.

The study has only identified the competencies required for successful entrepreneurs in India but has not designed and implemented program to develop them. Therefore, we cannot establish correlation between success of entrepreneurs and their competencies. That is a major limitation. India has more than 1.2 billion people coming from different regions and cultures and sample size of 67 may seem to be inadequate. Carrying out the study in different regions that covers larger sample may be required. We sought experts review individually. Since it is a smaller group, it may not be appropriate to look for statistical significance in their responses. Therefore, we believe having a Delphi session, with all of them, may be more helpful.

The entrepreneurial competencies are not only required to initiate start-ups but also to succeed in corporate careers. Today's corporate houses value engineers spotting opportunities for businesses, making decisions with a sense of personal, innate ownership and accountability, developing efficient and effective solutions and delivering value to customers. From that perspective, development of entrepreneurial competencies has broader appeal and requirements. 


\section{Acknowledgment}

We thank all the successful entrepreneurs who participated in the survey and the experts Mr. Ashok Saraf, Mr. Raju Goteti, Mr. Snehal Shah, Mr Abhay Joshi, and Mr Ashish Belagali who helped synthesize entrepreneurial competencies. We also thank Mr. Abhay Joshi and anonymous reviewers who, with their insightful comments, helped us improve quality of the paper.

\section{References}

$1 \quad$ Association Talent Development (ATD), 'The Atd Competency Model' <https://www.td.org/Certification/Competency-Model> [Accessed 26 Jan 2016.

2 Gregg A Lichtenstein, and Thomas S Lyons, Investing in Entrepreneurs: A Strategic Approach for Strengthening Your Regional and Community Economy (ABC-CLIO, 2010).

3 Yonca Gürol, and Nuray Atsan, 'Entrepreneurial Characteristics Amongst University Students: Some Insights for Entrepreneurship Education and Training in Turkey', Education+ Training, 48 (2006), 25-38.

4 Peter Gwynne, 'More Schools Teaching Entrepreneurship', Research Technology Management, 51 (2008), 6.

5 Tammy Schakett, Susan Schertzer, and Robert Kleine, 'Acculturating the Entrepreneurial Mindset', Business Journal for Entrepreneurs, 2015 (2015).

6 Entrepreneurship Education, 'A Guide for Educators', European Commission-DG Enterprise \& Industry, Brussels (2013).

7 Wendy EF Torrance, 'Entrepreneurial Campuses: Action, Impact, and Lessons Learned from the Kauffman Campuses Initiative', Ewing Marion Kauffman Foundation Research Paper (2013).

8 Lara Hulsey, Linda Rosenberg, and Benita Kim, 'Seeding Entrepreneurship across Campus: Early Implementation Experiences of the Kauffman Campuses Initiative', Available at SSRN 981057 (2006).

9 Alberta Charney, and Gary D Libecap, Impact of Entrepreneurship Education (Kauffman Center for Entrepreneurial Leadership Kansas City, MO, 2000).

10 Kwabena Nkansah Simpeh, 'Entrepreneurship Theories and Empirical Research: A Summary Review of the Literature', European Journal of Business and Management, 3 (2011), 1-8.

11 Thomas S Lyons, 'Policies for Creating an Entrepreneurial Region', Main Streets of Tomorrow: Growing and Financing Rural Entrepreneurs (2003), 97-106.

12 David A Kirby, 'Entrepreneurship Education: Can Business Schools Meet the Challenge?', Education+ training, 46 (2004), 510-19.

13 Einar Rasmussen, Simon Mosey, and Mike Wright, 'The Evolution of Entrepreneurial Competencies: A Longitudinal Study of University Spin-Off Venture Emergence', Journal of Management Studies, 48 (2011), 1314-45.

14 Susan Fredholm, James Krejcarek, Steven Krumholz, Dan Linquist, Sean Munson, Steve Schiffman, and John Bourne, 'Designing an Engineering Entrepreneurship Curriculum for Olin College', in Proceedings, American Society of Engineering Education (2002).

15 Timothy J Kriewall, and Kristen Mekemson, 'Instilling the Entrepreneurial Mindset into Engineering Undergraduates', The Journal of Engineering Entrepreneurship, 1 (2010), 5-19.

16 Nathalie Duval-Couetil, Jacob Wheadon, Elizabeth Kisenwether, and Joseph Tranquillo, 'Entrepreneurship and Abet Accreditation: How and Where Does It Fit?', in Frontiers in Education Conference, 2013 IEEE (IEEE, 2013), pp. 134-36.

17 Robert E Kleine, and John-David Yoder, 'Operationalizing and Assessing the Entrepreneurial Mindset: A Rubric Based Approach', The Journal of Engineering Entrepreneurship, 2 (2011), 57-86.

18 Dan Senor, and Saul Singer, Start-up Nation: The Story of Israel's Economic Miracle (Random House LLC, 2011).

19 'About Epicenter', 〈http://epicenter.stanford.edu/page/about> [Accessed 12-Jan-2016. 
TS Lyons, and JS Lyons, 'Assessing Entrepreneurship Skills: The Key to Effective Enterprise Development Planning', in 44th Annual Conference of the Association of Collegiate Schools of Planning. Baltimore, Maryland (2002), pp. 21-24.

21 John S Lyons, Communimetrics: A Communication Theory of Measurement in Human Service Settings (Springer Science \& Business Media, 2009).

SP Caird, 'General Measure of Enterprising Tendency Version 2 (Get2)', Entrepreneurship and innovation. Tilde University Press, Victoria (2006).

23 Mark H Davis, Jennifer A Hall, and Pamela S Mayer, 'Developing a New Measure of Entrepreneurial Mindset: Reliability, Validity, and Implications for Practitioners', (2015). Nassif E Rayess, and Ryan T Welsh, 'Entrepreneurial Engineering Training in a Freshman Design Course', (2015).

Liping Liu, James A Mynderse, Andrew L Gerhart, and Selin Arslan, 'Fostering the Entrepreneurial Mindset in the Junior and Senior Mechanical Engineering Curriculum with a Multi-Course Problem-Based Learning Experience', in Frontiers in Education Conference (FIE), 2015. 32614 2015. IEEE (IEEE, 2015), pp. 1-5.

Christopher J Creed, Eric M Suuberg, and Gregory P Crawford, 'Engineering Entrepreneurship: An Example of a Paradigm Shift in Engineering Education', Journal of Engineering Education, 91 (2002), 18595.

Sven G Bilán, Elizabeth C Kisenwether, Sarah E Rzasa, and John C Wise, 'Developing and Assessing Students' Entrepreneurial Skills and Mind-Set*', Journal of Engineering Education, 94 (2005), 233-43. Frontiers in Education, 2004. FIE 2004. 34th Annual (IEEE, 2004), pp. T2E/1-T2E/4 Vol. 1.

John-David Yoder, Robert Kleine, Don Carpenter, and Cynthia Fry, 'Spreading the Fire: Broadening Faculty Support for the Entrepreneurial Mindset', in National Collegiate Inventors and Innovators Alliance. Proceedings of the... Annual Conference (National Collegiate Inventors \& Innovators Alliance, 2013), p. 1. Steven P Nichols, and Neal E Armstrong, 'Engineering Entrepreneurship: Does Entrepreneurship Have a Role in Engineering Education?', Antennas and Propagation Magazine, IEEE, 45 (2003), 134-38. Regional Studies, 48 (2014), 1071-89. Are We Today and Where Should the Research Go in the Future', Entrepreneurship theory and practice, 32 (2008), 1-14. Dominic Wilson, Roopa Purushothaman, and Sachs Goldman, Dreaming with Brics: The Path to 2050. Vol. 99 (Goldman, Sachs \& Company, 2003). M.W. Peng, Business Strategies in Transition Economies. (Thousand Oaks, CA: Sage Publications., 2000). 'Global-Unemployment-(2011)-India-Leads-Pack-Equitymaster', EMMANUEL FAMILY MART PLAN, (<https://efmp.wordpress.com/what-next-after-college/40-million-unemployed-with-an-unemploymentrate-of-9-4/global-unemployment-2011-india-leads-pack-equitymaster/> [Accessed 12 Jan 2016. Headd Brian, 'An Analysis of Small Business and Jobs '2010) $<$ https://www.sba.gov/sites/default/files/files/an\%20analysis\%20of\%20small\%20business $\% 20$ and $\% 20$ jobs (1).pdf $>$. $179-83$. Analysis of Open-Ended Survey Responses', Organizational Research Methods, 5 (2002), 307-36.

41 Anne-Marie Pothas, Andries G De Wet, and Johannes Marthinus De Wet, 'Cus

42 Natalie L Sproull, Handbook of Research Methods: A Guide for Practitioners and Students in the Social Sciences (Scarecrow press, 2002).

43 Barney G Glaser, and Anselm L Strauss, 'The Constant Comparative Method of Qualitative Analysis', Social problems, 12 (1965), 436-45. 